\title{
MICROSATELLITE LOCI POLYMORPHISM IN RUSSIAN BLACK CURRANT (Ribes nigrum L.) VARIETIES FROM COLLECTION OF ALL-RUSSIAN RESEARCH INSTITUTE OF BREEDING FRUIT CROPS
}

\section{A.V. PIKUNOVA ${ }^{1}$, S.D. KNYAZEV ${ }^{1}$, A.Yu. BAKHOTSKAYA ${ }^{1}$, A.A. KOCHUMOVA ${ }^{2}$}

${ }^{1}$ All-Russian Research Institute of Breeding Fruit Crops, Russian Academy of Agricultural Sciences, p/o Zhilina, Orel Region, Orel Province, 302530 Russia, e-mail pikuanna84@mail.ru;

${ }^{2}$ N.I. Vavilov Institute of Genetics, Russian Academy of Sciences, 3, ul. Gubkina, Moscow, 119991 Russia, e-mail iogen@vigg.ru

Supported by Russian Science Foundation (project № 14-1600127) and Ministry of Education and Science of the Russian Federation (agreement № 8820)

Received July 1, 2013

\section{Abstract}

Black currant is the main berry crop in Russia. The need to improve its assortment requires new effective methods to be involved in breeding. Application of DNA markers as a modern approach in dealing with germplazm is intensively used abroad in works on black currant plants. We are the first in Russia who used SSR DNA markers in studying black currant gene pool. In this paper we report genotyping 27 black currant accessions from the collection of the All-Russian Research Institute of Breeding Fruit Crops, including 16 varieties originated from this institute, on 14 microsatellite loci. Electrophoresis in $6 \%$ denaturing PAAG followed by staining with silver nitrate was used for separation of PCR products. All tested SSR loci, except MS06g03, have been found to be polymorphic. On average 4.9 alleles were amplified per locus. Three fragments have been amplified on DNA of some accessions at one SSR locus that is probably due to the duplication of these microsatellite loci in genome of these accessions. A total of $66 \%$ of all amplified fragments were rare alleles with a frequency of occurrence equal to or less than 0.2. Eight unique alleles have been found. The observed heterozygosity ranged from 0.259 (g2-H21) to 1 (e4-D03) and averaged 0.608 . Combinations of alleles at one locus allowed to distinguish from 3 (g2- $\mathrm{H} 21$, e1-O21) to 15 (g2-G12) genotypes. The minimum set of four loci (e4-D03, g1-M07, g1-E03, g2-B20) allowed to distinguish all the tested accessions, i.e. unique multilocus profile has been found for each sample. Pairwise genetic similarity coefficients ranged from 0.11 (between Odzhebin and Sharovidnaya varieties) to 0.95 (between Govtva and Rtishchevskaya varieties) and averaged 0.346. Cluster analysis of genetic similarity has been done. The dendrogram shows a few clusters with high bootstrap support. Distribution of alleles between related varieties was consistent with the pedigrees in the most cases, but discrepancies between pedigrees and SSR data also were found. Thus, the varieties Ocharovanie (№ $1168 \times$ Ekzotika variety) and Ekzotika had no common alleles in three loci (e4$\mathrm{D} 03, \mathrm{~g} 1-\mathrm{E} 03, \mathrm{~g} 2-\mathrm{B} 20)$. It probably is due to pollination by other pollen or error in reproduction and transplantation or mutations in these loci. The varieties Odzhebin and Binar (Odzhebin $\times$ Naryadnaya) had no common alleles in two loci (g1-M07, g1-E03). Our results allow to recommend SSR markers for evaluation of domestic gene pool of black currant on genetic diversity, and to develop methods for the identification and certification of varieties of black currant.

Keywords: black currant, DNA markers, microsatellites, polymorphism, identification, gene pool, Ribes nigrum $\mathrm{L}$.

The black currant occupies half the areas under berries in Russia [1]. As of 2013, the State Register of Selection Achievements Permitted for Use included 170 varieties on this key berry crop [2]. About 20 scientific institutions in Russia are involved in enhancing the assortment of its varieties. Breeding studies are aimed at improving the biochemical composition of berries, creating productive, stably fruit-bearing varieties which are disease- and insect-resistant, suitable for machine harvesting, etc. [1]. In the All-Russian Research Institute of Breeding Fruit Crops (VNIISPK), 26 varieties (12 of them are included in the State Register of Varieties Permitted for Use) have been submitted for state variety testing by now. An extensive collection of variety specimens, including over 100 
introduced varieties and more than 700 home-bred forms, has been made.

The success of breeding studies greatly depends on investigation, selection and systematization of parent material [3]. The black currant has a diploid chromosome set $(n=7)$, which, to a certain extent, facilitates the study of its genome as compared to genomes of polyploid species. Scientists from the Scottish Crop Research Institute (Invergowrie, Dundee, Scotland, Great Britain) became pioneers in the use of DNA markers for genetic polymorphism analysis in the work with genetic resources of the black currant and other representatives of the genus Ribes L. They used RAPD (Random Amplified Polymorphic DNA), AFLP (Amplified Fragment Length Polymorphism), ISSR (InterSimple Sequence Repeat), SNP (Single Nucleotide Polymorphism) and other markers $[4,5]$. As a result, based on microsatellite SNP and AFLP markers, the first genetic map of the black currant has been created [6], and a method for marker-mediated selection of genotypes with gall mite resistance gene $\mathrm{Ce}$ has been developed and is used [7]. In Russia, DNA marking for assessment of genetic collection of genus Ribes representatives has only been used relatively recently [8].

At present, we observe a tendency towards the use of highly reproducible codominant SSR and SNP markers. SSR (microsatellite) markers are used both in fundamental studies aimed at assessing genetic polymorphism, investigating phylogenetic relationships and creating genetic maps for linkage groups, and for application-oriented purposes, such as genealogy checking, development of identification and certification systems, search for the markers associated with economic characters, and marker-mediated selection of targeted genotypes at early stages of plant development [9]. SSR markers have been used for assessing the diversity of genetic collections of Ribes in Italy and North Europe [10, 11].

We were the first who used microsatellite markers for assessing intervarietal polymorphism, determining genetic similarity between variety specimens and checking the genealogy for black currant forms from the Russian collection of VNIISPK, which allowed us to discuss the prospects of using the polymorphism of microsatellite loci in work with the genetic resources of this berry crop.

The presented study was aimed at investigating the polymorphism of microsatellite loci for black currant varieties from VNIISPK's collection.

Technique. There were 27 varieties of the black currant from the collection of the All-Russian Research Institute of Breeding Fruit Crops, including 16 varieties bred by VNIISPK (Azhurnaya, Gratsiya, Gamma, Dachnitsa, Orlovsky Vals, Monisto, Orloviya, Iskusheniye, Chudnoye Mgnoveniye, Ocharovaniye, Slastena, Chernaya Vual, Ekzotika, Blakeston, Zusha, Kipiana), as well as varieties from other originators (Odzhebin, Titaniya, Sharovidnaya, Selechenskaya, Minai Shmyrev, Rtishchevskaya, Konsort, Binar, Govtva, Kanakhama, Yadrenaya) involved in the investigation. In addition, varieties Lentyai and Orlovskaya Serenada were analyzed by a part of the loci used. The results obtained for these varieties were taken into account only in the correspondence analysis of allele distribution between related varieties and analysis of genealogy data (allele distribution between related varieties was checked with all polymorphic loci, for which such data were available).

DNA was extracted from juvenile leaves using the CTAB method [12].

We have analyzed a total of 14 microsatellite loci (http://www.fruitbreeding.co.uk/RibesGenomicsSSRs.asp), i.e. e1-O01, e1-O21, e3-B02, e4-D03, g1-B02, g1-E03, g1-K04, g1-M07, g2-B20, g2-H21, g2-J08, g2-L17, g2-G12, MS06g03 [13]. The PCR analysis was carried out in $20 \mu \mathrm{l}$ of reaction mixture containing $1 \times$ PCR buffer, $200 \mu \mathrm{M}$ of nucleotides, $2 \mu \mathrm{M}$ of forward primer, 2 $\mu \mathrm{M}$ of reverse primer, $0.3 \mathrm{U}$ of Taq DNA polymerase and $10 \mathrm{ng}$ of DNA in a 
GeneAmp PCR System 9700 thermocycler (Applied Biosystems, USA). The amplification reaction was carried out under the following conditions: preliminary denaturation for $5 \mathrm{~min}$ at $94{ }^{\circ} \mathrm{C}$; denaturation for $30 \mathrm{~s}$ at $94{ }^{\circ} \mathrm{C}$, primer annealing (at the temperature selected for each marker; refer to the «Results» section), DNA synthesis for $30 \mathrm{~s}$ at $72{ }^{\circ} \mathrm{C}$ (total 35 cycles); final elongation for 10 $\min$ at $72{ }^{\circ} \mathrm{C}$.

The polymorphism of microsatellite loci was analyzed using electrophoretic separation of amplificates in $6 \%$ denaturing polyacrylamide gel (PAAG) in a Sequi-Gen GT System chamber $(38 \times 50 \mathrm{~cm})$ (Bio-Rad, USA) with subsequent staining with silver nitrate [14]. The sizes of fragments were determined by comparison with molecular weight marker 10 bp DNA Ladder (Invitrogen ${ }^{\mathrm{TM}}$, USA).

The allele frequency was calculated as a sum of homozygous genotype frequencies and a half-sum of frequencies of heterozygous genotypes containing this allele [15]. The expected heterozygosity was calculated as $\mathrm{H}_{\mathrm{e}}=1-\mathrm{p}_{\mathrm{i}}{ }^{2}$, where $\mathrm{p}_{\mathrm{i}}$ is a frequency of the $i$-th allele. In order to estimate the observed heterozygosity $\left(\mathrm{H}_{\mathrm{o}}\right)$ in the corresponding locus, the number of heterozygous specimens was divided by the total number of specimens. Alleles with the frequency of 0.2 and less were considered as rare. The allele frequency, probability of identity in accordance with the Hardy-Weinburg law, HW P(ID), and probability of identity in sib analysis, Sib P(ID), were determined using the GENECAP software program [16]. The null allele frequency ( $r$ ) was calculated by the formula $\mathrm{r}=\left(\mathrm{H}_{\mathrm{e}}-\mathrm{H}_{\mathrm{H}}\right) /\left(1+\mathrm{H}_{\mathrm{o}}\right)$. The Jaccard similarity coefficient calculation [17] and dendrogram construction were carried out using the PAST software program [18]. The dendrogram was constructed by the Unweighted Pair Group Method with Arithmetic Mean (UPGMA) [19] using a Jaccard coefficient; number of replications is 1,000 .

Results. The analysis of 14 microsatellite loci (Table 1) for 27 currant variety specimens has revealed loci having from 1 (MS06g03) to 8 (e4-D03) alleles, which was equal to 4.9 alleles per locus on average. In this case, all loci but MS06g03 were polymorphic.

1. The designations and amplification conditions of the microsatellite loci used for the analysis of black currant (Ribes nigrum L.) variety specimens from the collection of All-Russian Research Institute of Breeding Fruit Crops

\begin{tabular}{|c|c|c|c|c|}
\hline Locus & $\begin{array}{l}\text { Linkage } \\
\text { group }^{\mathrm{a}}\end{array}$ & Forward primer & Reverse primer & $\mathrm{T},{ }^{\circ} \mathrm{C}$ \\
\hline e1-O01 & 6 & CCT TTC CAG AGA AAA CTC AAA CA & AAG TAT GGG AAC AAC GGC AG & 52 \\
\hline e1-O21 & 4 & TCT CTC CAA CTG AGA AGG AAA A & GAT TTG TTC TTG TGC AGC GA & 50 \\
\hline e3-B02 & 5 & AAG ACG AAG ACG ACG ACG AT & CTG ATC TTT GCC GAA TGG TT & 52 \\
\hline e4-D03 & 3 & CCC AAA AGC AAA TTT AGG GT & GTG AGG CAT GGA ACC ACT TT & 56 \\
\hline g1-B02 & 2 & CGA CTT CAT CGC TCT CCT CT & CCA TTG ATT TGG TGA GGG T & 50 \\
\hline g1-E03 & 1 & TAA CTG CGG GGT TCC TAC AG & CCA CCG CTA CCA ATA ACC AT & 56 \\
\hline g1-K04 & 1 & TGT TCC CTG TTT CCT TCA AAA & GGA CGT GGA CGA TGA GAG TT & 52 \\
\hline g1-M07 & 1 & TCC CGT TAC TGG AGT GGT GT & CCA TGG TTT TCC GAT TTG TT & 52 \\
\hline $\mathrm{g} 2-\mathrm{B} 20$ & 3 & CTC CAT CAA ATC CCT CGT TT & TCT TGC TTC CCA AAC AGT ATC A & 52 \\
\hline g2-H21 & 4 & TGC CCT TTT TGG TCA TTT TC & CAA TCG TCG ATG AAG GTC TG & 50 \\
\hline g2-J08 & 2 & CGC CGA GCT CTA ATC ACT GT & ATA GCC CAT GCC CAT ATT CA & 54 \\
\hline g2-L17 & 4 & TTT GGA AAA CCT CCC CTT TT & GAG CTG TTG CTG TTG CCA TA & 50 \\
\hline g2-G12 & 7 & GTG ACC CAC CTA AAC CGT CC & GGA GTG GAG GGT TGG AAA AT & 52 \\
\hline MS06g03 & $\mathrm{b}$ & CGG AGG GTG TGC CGA AG & GCC CAG CCC ATA TCT GCT & 52 \\
\hline
\end{tabular}

For all black currant loci but MS06g03, we know the position of linkage groups on the genetic map (in particular, the analyzed loci are located in 7 different linkage groups) [6]. Primers for locus MS06g03 were initially developed based on an apple tree DNA sequence and mapped in linkage group 10 in a family obtained by of crossing of varieties Fiesta $\times$ and Discovery. MS06g03 is considered as a multilocus marker: in case of the apple tree, its amplification re- 
sults in DNA fragments of 154-190 base pairs [13], and a fragment with the length of 140 base pairs is observed for all currant variety specimens. It is likely that this locus is located in the quite conservative part of the black currant genome.

In the majority of cases, maximum two fragments were identified for a specific locus for each genotype; however, for a number of specimens, three fragments were amplified in some loci (g2-B20 for variety Yadrenaya, e1-O01 for variety Selechenskaya, and in e3-B02 for Gamma, Gratsiya, Orloviya, Chernaya Vual, Sharovidnaya, Zusha, Kipiana). It is reported about amplification of more than two alleles in some microsatellite loci of diploid forms, which is associated with duplication of microsatellite loci either on the same chromosome or different chromosomes [20].

Based on the microsatellite profiles of 27 variety specimens, we have analyzed allele distribution for 13 of the polymorphic loci used (Table 2).

2. The characteristics of 13 polymorphic microsatellite loci identified for 27 black currant (Ribes nigrum L.) variety specimens from the collection of All-Russian Research Institute of Breeding Fruit Crops

\begin{tabular}{|c|c|c|c|c|c|c|c|c|c|c|c|c|c|}
\hline \multirow{2}{*}{$\frac{\text { Locus }}{\mathrm{e} 1-\mathrm{O} 01}$} & \multirow{2}{*}{$\begin{array}{l}n \\
6\end{array}$} & \multicolumn{8}{|c|}{ Allele size, base pairs (frequency) } & \multirow{2}{*}{$\begin{array}{c}\mathrm{H}_{\mathrm{e}} \\
0.737\end{array}$} & \multirow{2}{*}{$\begin{array}{c}\mathrm{H}_{\mathrm{O}} \\
0.769\end{array}$} & \multirow{2}{*}{\begin{tabular}{|c|}
$r$ \\
-0.019
\end{tabular}} & \multirow{2}{*}{$\begin{array}{l}\mathrm{A}, \mathrm{B} \\
0.402, \\
0.101\end{array}$} \\
\hline & & $\begin{array}{l}138^{\mathrm{a}} \\
(0.093)\end{array}$ & $\begin{array}{l}140^{\mathrm{ab}} \\
(0.023)\end{array}$ & $\begin{array}{l}142 \\
(0.419)\end{array}$ & $\begin{array}{l}145^{\mathrm{a}} \\
(0.163)\end{array}$ & $\begin{array}{l}147 \\
(0.209)\end{array}$ & $\begin{array}{l}149^{\mathrm{a}} \\
(0.093)\end{array}$ & & & & & & \\
\hline e1-O21 & 3 & $\begin{array}{l}288^{a b} \\
(0.029)\end{array}$ & $\begin{array}{l}292 \\
(0.714)\end{array}$ & $\begin{array}{l}294 \\
(0.257)\end{array}$ & & & & & & 0.423 & 0.407 & 0.011 & $\begin{array}{l}0.639, \\
0.402\end{array}$ \\
\hline e3-B02 & 4 & $\begin{array}{l}188 \\
(0.486)\end{array}$ & $\begin{array}{l}191 \\
(0.257)\end{array}$ & $\begin{array}{l}193^{\mathrm{a}} \\
(0.200)\end{array}$ & $\begin{array}{l}194^{\mathrm{a}} \\
(0.057)\end{array}$ & & & & & 0.655 & 0.800 & -0.088 & $\begin{array}{l}0.467, \\
0.177\end{array}$ \\
\hline e4-D03 & 8 & $\begin{array}{l}197 \mathrm{a} \\
(0.180)\end{array}$ & $\begin{array}{l}201^{\mathrm{a}} \\
(0.100)\end{array}$ & $\begin{array}{l}205^{\mathrm{a}} \\
(0.160)\end{array}$ & $\begin{array}{l}207^{a b} \\
(0.020)\end{array}$ & $\begin{array}{l}210^{\mathrm{a}} \\
(0.200)\end{array}$ & $\begin{array}{l}212^{\mathrm{a}} \\
(0.200)\end{array}$ & $\begin{array}{l}217^{\mathrm{a}} \\
(0.100)\end{array}$ & $\begin{array}{l}224^{\mathrm{a}} \\
(0.040)\end{array}$ & 0.840 & 1.000 & -0.087 & $\begin{array}{l}0.342 \\
0.046\end{array}$ \\
\hline g1-B02 & 3 & $\begin{array}{l}203 \\
(0.231)\end{array}$ & $\begin{array}{l}205 \\
(0.513)\end{array}$ & $\begin{array}{l}207 \\
(0.256)\end{array}$ & & & & & & 0.610 & 0.590 & 0.016 & $\begin{array}{l}0.495 \\
0.216\end{array}$ \\
\hline g1-E03 & 7 & $\begin{array}{l}232^{\mathrm{ab}} \\
(0.025)\end{array}$ & $\begin{array}{l}235 \\
(0.400)\end{array}$ & $\begin{array}{l}237 \\
(0.275)\end{array}$ & $\begin{array}{l}239^{\mathrm{a}} \\
(0.175)\end{array}$ & $\begin{array}{l}245^{\mathrm{a}} \\
(0.075)\end{array}$ & $\begin{array}{l}249^{\mathrm{ab}} \\
(0.025)\end{array}$ & $\begin{array}{l}270^{\mathrm{a}} \\
(0.025)\end{array}$ & & 0.726 & 0.593 & 0.077 & $\begin{array}{l}0.416, \\
0.118\end{array}$ \\
\hline g1-K04 & 4 & $\begin{array}{l}285^{a b} \\
(0.026)\end{array}$ & $\begin{array}{l}290 \\
(0.605)\end{array}$ & $\begin{array}{l}295 \\
(0.237)\end{array}$ & $\begin{array}{l}298^{\mathrm{a}} \\
(0.132)\end{array}$ & & & & & 0.560 & 0.556 & 0.003 & $\begin{array}{l}0.530 \\
0.250\end{array}$ \\
\hline g1-M07 & 7 & $\begin{array}{l}200^{\mathrm{a}} \\
(0.140)\end{array}$ & $\begin{array}{l}204^{\mathrm{a}} \\
(0.140)\end{array}$ & $\begin{array}{l}207^{\mathrm{a}} \\
(0.047)\end{array}$ & $\begin{array}{l}209 \\
(0.442)\end{array}$ & $\begin{array}{l}212^{\mathrm{a}} \\
(0.140)\end{array}$ & $\begin{array}{l}217 \mathrm{a} \\
(0.070)\end{array}$ & $\begin{array}{l}222^{\mathrm{ab}} \\
(0.023)\end{array}$ & & 0.739 & 0.704 & 0.020 & $\begin{array}{l}0.405, \\
0.097\end{array}$ \\
\hline g2-B20 & 5 & $\begin{array}{l}147^{\mathrm{a}} \\
0.189\end{array}$ & $\begin{array}{l}168^{\mathrm{a}} \\
0.135\end{array}$ & $\begin{array}{l}178 \\
0.432\end{array}$ & $\begin{array}{l}181^{\mathrm{a}} \\
0.189\end{array}$ & $\begin{array}{l}185^{\mathrm{a}} \\
0.054\end{array}$ & & & & 0.720 & 0.556 & 0.096 & $\begin{array}{l}0.420 \\
0.119\end{array}$ \\
\hline g2-H21 & 3 & $\begin{array}{l}265^{\mathrm{a}} \\
(0.156)\end{array}$ & $\begin{array}{l}267 \\
(0.781)\end{array}$ & $\begin{array}{l}273^{\mathrm{a}} \\
(0.063)\end{array}$ & & & & & & 0.361 & 0.259 & 0.075 & $\begin{array}{l}0.680, \\
0.443\end{array}$ \\
\hline g2-J08 & 4 & $\begin{array}{l}158^{\mathrm{a}} \\
0.083\end{array}$ & $\begin{array}{l}160 \\
0.667\end{array}$ & $\begin{array}{l}162^{\mathrm{a}} \\
0.167\end{array}$ & $\begin{array}{l}164^{\mathrm{a}} \\
0.083\end{array}$ & & & & & 0.514 & 0.444 & 0.046 & $\begin{array}{l}0.562, \\
0.274\end{array}$ \\
\hline g2-L17 & 6 & $\begin{array}{l}150^{\mathrm{a}} \\
(0.063)\end{array}$ & $\begin{array}{l}152^{\mathrm{a}} \\
(0.063)\end{array}$ & $\begin{array}{l}154^{\mathrm{a}} \\
(0.094)\end{array}$ & $\begin{array}{l}161 \\
(0.625)\end{array}$ & $\begin{array}{l}168^{\mathrm{a}} \\
(0.094)\end{array}$ & $\begin{array}{l}171^{\mathrm{a}} \\
(0.063)\end{array}$ & & & 0.580 & 0.296 & 0.180 & $\begin{array}{l}0.510 \\
0.200\end{array}$ \\
\hline g2-G12 & 7 & $\begin{array}{l}190^{\mathrm{ab}} \\
(0.022)\end{array}$ & $\begin{array}{l}195^{\mathrm{a}} \\
(0.178)\end{array}$ & $\begin{array}{l}203^{\mathrm{a}} \\
(0.089)\end{array}$ & $\begin{array}{l}207^{\mathrm{a}} \\
(0.089)\end{array}$ & $\begin{array}{l}209^{\mathrm{a}} \\
(0.156)\end{array}$ & $\begin{array}{l}212 \\
(0.244)\end{array}$ & $\begin{array}{l}215 \\
(0.222)\end{array}$ & & 0.997 & 0.926 & 0.035 & $\begin{array}{l}0.355, \\
0.058\end{array}$ \\
\hline Average & & & & & & & & & & 0.652 & 0.608 & & $\begin{array}{l}0.192, \\
0.479\end{array}$ \\
\hline
\end{tabular}

N o t e: A - Sib P(ID) (probability of identity in sib analysis), B - HW P(ID) (probability of identity in accordance with the Hardy-Weinburg law); $n-$ number of alleles, a - rare alleles, b - unique alleles amplified in one of 27 variety specimens studied.

The expected heterozygosity varied from 0.361 in locus g2-H21 to 0.997 in locus g2-G12 (0.652 on average), whereas the observed heterozygosity varied from 0.259 in locus g2-H21 to 1 in locus e4-D03 (0.608 on average). Thus, the average values of the observed and expected heterozygosity did not differ much, which was due to the nature of the object under study. As is known, allogamous plants, including the black currant, are characterized by greater heterozygosity than autophilous ones [15]. In addition, vegetative reproduction of fruit and berry crops makes it possible to fix the heterozygous state of the genotype regardless of how stable the recurrence of characters in the first generation might be. Therefore, distinctive features of such crops include high heterozygosity which is only strengthened by the use of a remote hybridization method and involvement of different species in the breeding process. 
3. The variety-specific fragments amplified in the microsatellite loci of the black currant (Ribes nigrum L.) from the collection of All-Russian Research Institute of Breeding Fruit Crops

\begin{tabular}{ll}
\hline \multicolumn{1}{c}{ Variety specimen } & \multicolumn{1}{c}{ Locus/size of fragment } \\
\hline Orloviya & g1-K04/285 base pairs, \\
& g1-E03/232 base pairs \\
Odzhebin & g1-M07/222 base pairs \\
Monisto & e4-D03/207 base pairs \\
Minai Shmyrev & e1-O21/288 base pairs \\
Binar & e1-O01/140 base pairs \\
Titaniya & g1-E03/249 base pairs \\
Sharovidnaya & g2-G12/190 base pairs \\
\hline
\end{tabular}

from -0.088 to 0.180 .

The probability of identity of two genotypes, HW P(ID), varied from 0.046 for locus e4-D03 to 0.443 for locus g2-H21 ( 0.203 on average), and the probability of identity of two sibs, Sib P(ID), varied from 0.342 for locus e4-D03 to 0.680 for locus g2-H21 ( 0.489 on average).

A total of 45 of 68 alleles amplified in 14 loci $(66 \%)$ corresponded to rare alleles with the frequency equal to or smaller than 0.2 . Also, eight unique fragments amplified only on DNA of one of the tested specimen varieties have been identified (Table 3).

Combinations of alleles in one locus allowed us to distinguish from 3 (g2-H21, e1-O21) to 15 (g2-G12) genotypes. For example, five combinations of alleles (genotypes) were observed in locus g1-K04 with 4 amplified alleles, and variety Orloviya had a unique allele with the size of about 285 base pairs (Fig. 1).

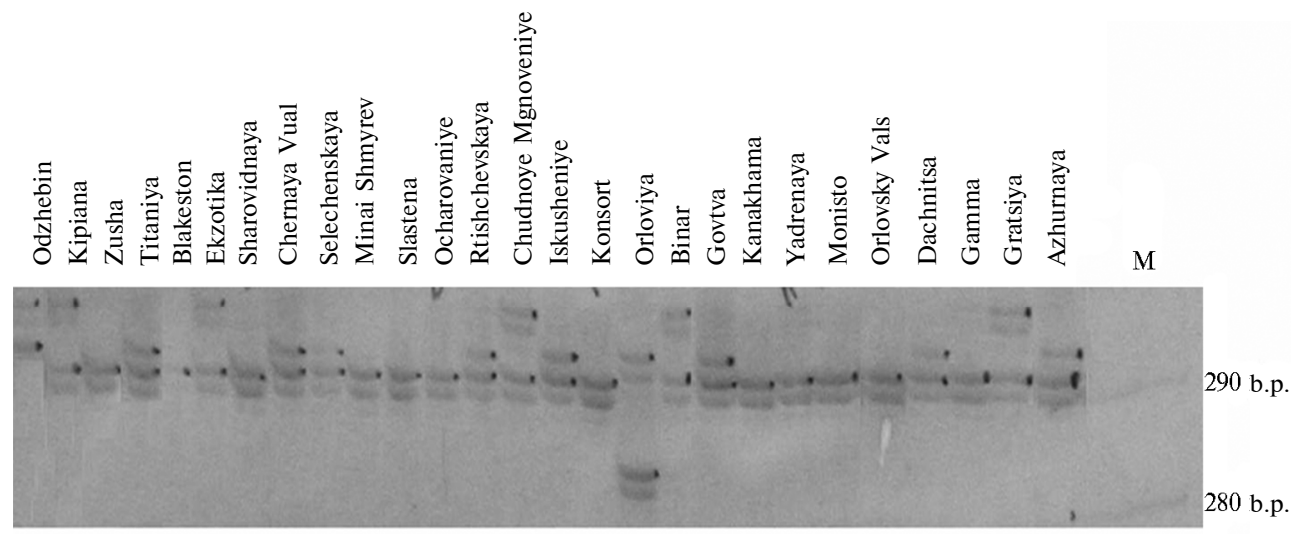

$\begin{array}{llll}2 & 3 & 4 & 5\end{array}$

Fig. 1. The electrophoretogram of the fragments of microsatellite locus g1-K04 amplification for 27 studied specimen varieties of the black currant (Ribes nigrum L.) from the collection of All-Russian Research Institute of Breeding Fruit Crops: 1-5 - conditional genotypes according to locus; $\mathrm{M}$ - molecular weight marker (10 bp DNA Ladder, Invitrogen ${ }^{\mathrm{TM}}$, USA; fragment sizes are indicated on the right).

The minimum set of four loci (e4-D03, g1-M07, g1-E03, g2-B20) allowed us to distinguish all the tested variety specimens, i.e. a unique multilocus profile was obtained for each specimen.

Based on SSR spectra, we have constructed a similarity dendrogram for 27 variety specimens of the black currant (Fig. 2). The obtained pairwise genetic similarity coefficients ranged from 0.11 (between varieties Odzhebin and Sharovidnaya) to 0.95 (between varieties Govtva and Rtishchevskaya) with the 
average value of 0.346 .

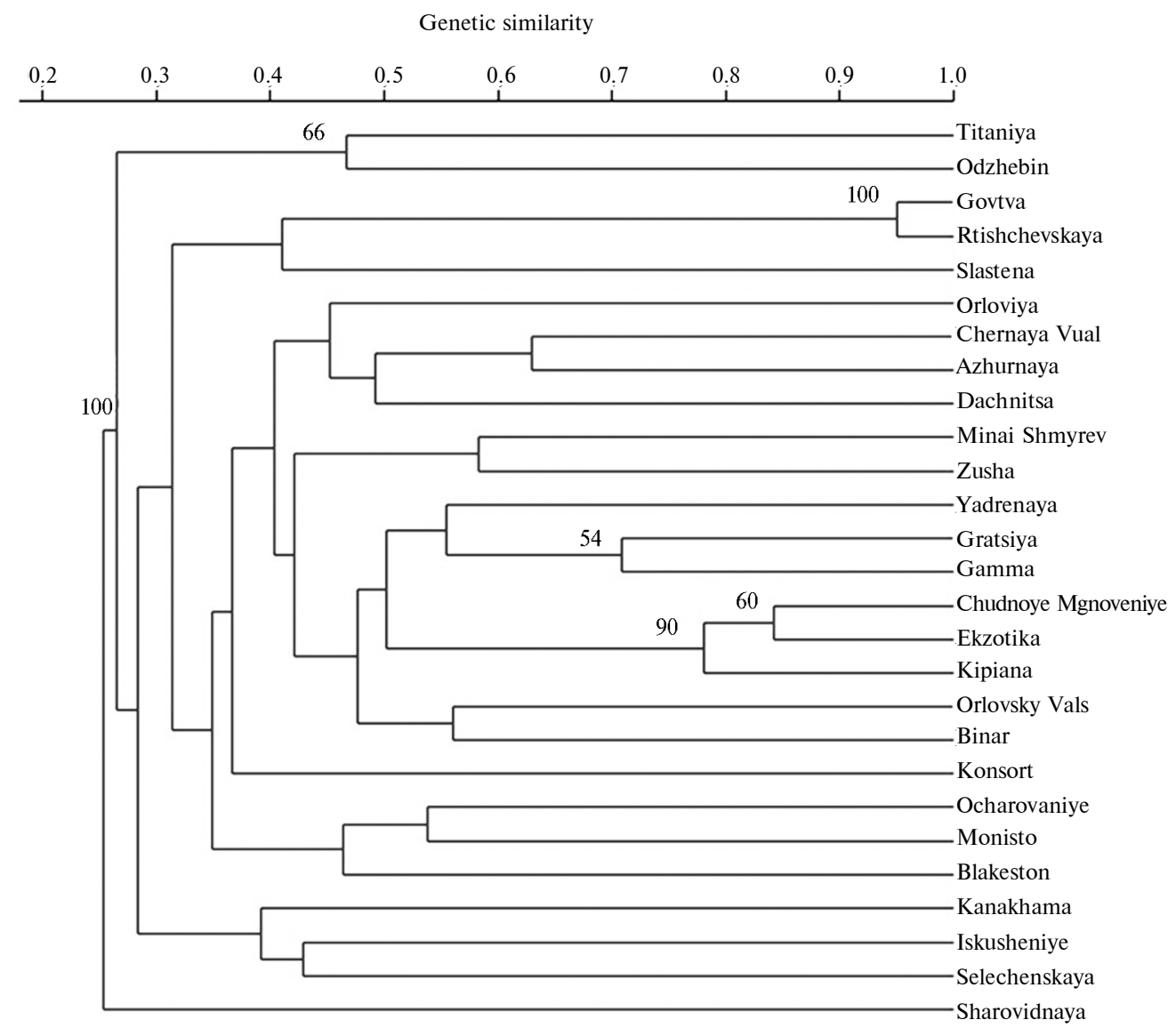

Fig. 2. The similarity dendrogram for 27 variety specimens of the black currant (Ribes nigrum L.) from the collection of All-Russian Research Institute of Breeding Fruit Crops, which was constructed based on the analysis of polymorphism of 13 microsatellite loci (the bootstrap values shown).

The dendrogram showed several distinct clusters with high bootstrap support (BS). At a short genetic distance, varieties Govtva and Rtishchevskaya (BS 100\%) were collectively clustered. Varieties Chudnoye Mgnoveniye and Ekzotika merged at a somewhat greater genetic distance (BS $60 \%$ ); their parent forms are seedlings from one family. Then, variety Kipiana joined them (BS $90 \%$ ); its male parent was variety Ekzotika. Varieties Gamma and Gratsiya derived by selection from the same hybrid family as variety Kipiana were clustered separately from varieties Ekzotika and Kipiana. According to the data of RAPD analysis, clustering of varieties Gamma and Gratsiya with a high BS value was also observed, whereas variety Kipiana was not a part of this cluster [8]. This may indicate that varieties Gamma and Gratsiya are genetically more similar to each other than to varieties Kipiana and Ekzotika. An individual cluster was also formed by Swedish varieties Titaniya and Odzhebin (BS $66 \%$ ) having a Scandinavian subspecies of the black currant in their genealogy.

The analysis of allele flow through the genealogies of the related varieties has shown that, in the majority of cases, allele distribution between them was not in conflict with the genealogies. Thus, parent variety Lentyai and its derivatives in the first generation (varieties Azhurnaya, Orlovsky Vals, Slastena) had at least one common allele for all tested microsatellite loci. The same occurred 
with variety Minai Shmyrev and the varieties derived from it the first generation (Zusha, Lentyai, Orlovskaya Serenada), as well as with variety Ekzotika and its descendants in the first generation (varieties Kipiana, Gamma, Gratsiya). However, variety Ocharovaniye, for which variety Ekzotika was a male parent according to the genealogy, had no common alleles in three loci (e4-D03, g1-E03, g2-B20). It is probably due to pollination by other pollen, or an error in reproduction and transplantation, or mutations in these loci. Varieties Odzhebin and Binar (derived by crossing of Odzhebin $\times$ Naryadnaya) had no common alleles in two microsatellite loci (g1-M07 and g1-E03).

In some cases, during genotyping of microsatellite loci of collected black currant varieties from North Europe, it was impossible to confirm genetic identity of same-name specimens from various collections, for example, one of 10 specimens of variety Odzhebin turned out to be non-identical to the other specimens [11]. S. Reim et al. used 11 microsatellite loci in order to clarify the origin of the varieties bred in Dresden-Pillnitz [21]. As a result, in a number of cases, it became evident which variety was involved in hybridization with pollination with mixed pollen of different varieties, and for some varieties, unreliability of genealogies was established both for female and male parent forms.

So, we were the first who carried out genotyping of black currant (Ribes nigrum L.) microsatellite loci in Russia. It has been established that the microsatellite loci have high polymorphism, and also rare and unique alleles have been identified, which made it possible to obtain a unique multilocus profile for each tested specimen. It is shown that we may check the relationship of specimens based on the analysis of microsatellite allele distribution. The obtained data indicate that there are good prospects for using the tested markers in the assessment of genetic diversity of the domestic black currant gene pool, as well as in the development of methods for identification and certification of varieties, which may be used for breeders' copyright protection.

\section{REFERE N C ES}

1. K n y a z e v S.D., Og o l't s o v a T.P. Selektsiya smorodiny chernoi na sovremennom etape [Blackcurrant breeding: modern steps]. Orel, 2004.

2. Gosudarstvennyi reestr selektsionnykh dostizhenii, dopushchennykh $k$ ispol'zovaniyu. Tom 1. Sorta rastenii [State Register of breeding achievements permitted for use. V. 1.]. Moscow, 2013.

3. V a vilo v N.I. Teoreticheskie osnovy selektsii [Theoretical basis for breeding]. Moscow, 1987.

4. Lanham P., B re nnan R.M., H a c k e t t C., M c N i c o l R.J. RAPD fingerprinting of blackcurrant (Ribes nigrum L.) cultivars. Theoretical and Applied genetics, 1995, 90: 166-172 (doi: 10.1007/BF00222198).

5. Brennan R., Jorgensen L., Woodhead M., Russe 11 J. Future perspectives in blackcurrant breeding. Acta Horticulture, 2002, 585: 39-45.

6. Brennan R., Jorgensen L., H a cket t C., Woodhe ad M., Gordon S.L., Rus s e 11 J. The development of a genetic linkage map of blackcurrant (Ribes nigrum L.) and the identification of regions associated with key fruit quality and agronomic traits. Euphytica, 2008, 161: 19-34 (doi: 10.1007/s10681-007-9412-8).

7. Brennan R., Jorgensen L., Gordon S.L., Loades K., Hackett C., Rus s e $11 \mathrm{~J}$. The development of a PCR-based marker linked to resistance to the blackcurrant gall mite (Cecidophyopsis ribis Acari: Eriophyidae). Theor. Appl. Genet., 2009, 118: 205-211 (doi: 10.1007/s00122-008-0889-x).

8. Pikunova A.V., Martirosyan E.V., Knyazev S.D., Ryzhova N.N. Ekologicheskaya genetika, 2011, IX(2): 34-44.

9. Kalia R.K., Rai M.K., K alia S., S i ngh R., D haw a n A.K. Microsatellite markers: an overview of the recent progress in plants. Euphytica, 2011, 177(3): 309-334 (doi: 10.1007/s10681-010-0286-9).

10. Cavanna M., M a ri noni D.T., B e c a ro G.L., B o u nous G. Microsatellite-based evaluation of Ribes spp. germplasm. Genome, 2009, 52: 839-848 (doi: 10.1139/G09-057).

11. Antonius K., Karhu S., Kaldm H., Lacis G., Rugenius R., Baniulis D., Sasnauskas A., Schulte E., Kuras A., Korbin M., Gunnarsson A., 
Werlemark G., Ryliskis T.-A.T., Kokk L., Jarve K. Development of the Northern European Ribes core collection based on a microsatellite (SSR) marker diversity analysis. Plant Genetic Resources: Characterization and Utilization, 2012, 10: 70-73 (doi: 10.1017/S1479262111000980).

12. D o y le J.J., D o y le J.L. Isolation of plant DNA from fresh tissue. Focus, 1990, 12: 13-15.

13. Liebhard R., Gianfranceschi L., Koller B., Ryder C.D., Tarchini R., Van de Weg E., Gessler C. Development and characterization of 140 new microsatellites in apple (Malus $\times$ domestica Borkh.). Mol. Breed., 2012, 10: 217-241.

14. Maniatis T., Frich E., S e mbruk Dzh. Metody geneticheskoi inzhenerii. Molekulyarnoe klonirovanie [Methods in genetic engineering. Molecular cloning]. Moscow, 1984.

15. Gaevskii N.A. Znakomstvo s evolyutsionnoi genetikoi [Knowing molecular genetics]. Krasnoyarsk, 2002.

16. Wilberg M.J., D re her B.P. Genecap: a program for analysis of multilocus genotype data for non-invasive sampling and capture-recapture population estimation. Molecular Ecology Notes, 2004, 4(4): 783-785.

17. J a c card P. Distribution de la flore alpine dans le Bassin des Dranses et dans quelques regions voisines. Bull. Soc. Vaudoise sci. Natur., 1901, 37(140): 241-272.

18. $\mathrm{H}$ a m m e $\mathrm{r}$ I., $\mathrm{H}$ a rpe $\mathrm{r}$ D.A.T., Ry a $\mathrm{n}$ P.D. PAST: Paleontological statistics software package for education and data analysis. Palaeontologia Electronica, 2001, 4(1): 9 (http://palaeo-electronica.org/2001_1/past/issue1_01.htm).

19. S n e a th P.H.A., S o k a 1 R.R. Numerical taxonomy: theprinciples and practice of numerical classification. San Francisco, 1973.

20. G a 11 i Z., Ha lás z G., K iss E., Heszky L., Dobráns zki J. Molecular identification of commercial apple cultivars with microsatellite markers. Horticult. Sci., 2005, 40: 1974-1977.

21. Reim S., Flachowsky H., Hanke M.V., Peil A. Verifying the parents of the Pillnitzer apple cultivars. Acta Horticulture, 2009, 814: 319-323. 